\title{
DESAIN KUALITAS JASA PENGIRIMAN PADA PT. X DENGAN PENDEKATAN HOUSE OF QUALITY
}

\author{
Dina Paulina 1 \\ Ni Ketut Purnawati ${ }^{2}$ \\ ${ }^{1,2}$ Fakultas Ekonomi dan Bisnis Universitas Udayana (Unud), Bali, Indonesia \\ email: dinapaulina02@gmail.com
}

\begin{abstract}
ABSTRAK
Desain jasa bertujuan agar jasa yang ditawarkan dapat memenuhi harapan pelanggan. Salah satu alat yang dapat digunakan dalam desain jasa adalah Quality Function Deployment dengan House of Quality, yang menghubungkan keinginan pelanggan dan kemampuan perusahaan dalam menanggapinya, selain itu dapat mengetahui posisi perusahaan dalam persaingan. Populasi penelitian adalah seluruh pelanggan PT. X dan pesaingnya dengan sampel sebanyak 115 responden menggunakan purposive sampling. Hasil menunjukkan PT. $\mathrm{X}$ belum mampu memenuhi keinginan atau kebutuhan pelanggan dengan baik dilihat dari adanya gap antara tingkat kepentingan dengan tingkat kinerja perusahaan. Terdapat 7 indikator pelayanan jasa yang menjadi kebutuhan pelanggan atau customer requirement dan 7 technical requirement, walaupun perbedaanya tidak jauh namun posisi PT. X masih dibawah pesaingnya dan membutuhkan perbaikan untuk meningkatkan kepuasan pelanggan. Kata kunci : Desain jasa, QFD, House of Quality
\end{abstract}

\begin{abstract}
Service design is intended so that the services offered can meet customer expectations. One of the tools that can be used in service design is Quality Function Deployment with the House of Quality, which connects customer desires and the company's ability to respond to them, besides knowing the company's position in competition. The study population are all customers of PT. $X$ and its competitors with 115 people as samples through purposive sampling. Results show PT.X has not been able to fulfill customer wants or needs properly, seen from the gap between level of interest and the level of company performance. There are 7 service indicators that become customer needs or customer requirements and 7 technical requirements, although the difference is not that far, position of PT. X is still below its competitors and needs improvement to increase customer satisfaction.
\end{abstract}

Keywords: Design services, QFD, House of Quality 


\section{PENDAHULUAN}

Persaingan bisnis yang semakin ketat, menimbulkan banyak konsekuensi dalam persaingan perusahaan. Perusahaan dituntut untuk meningkatkan daya saingnya secara terus menerus (Yuen \& Thai, 2015). Perusahaan dalam waktu cepat harus mampu mengubah diri menjadi lebih kuat dan mampu menanggapi kebutuhan pasar. Perusahaan dapat meningkatkan daya saingnya dengan memberikan pelayanan cepat dan tepat. Perusahaan dapat mendesain kualitas pelayanan sehingga menjadi lebih unggul dari pesaing (Sun et al., 2015). Desain pelayanan dapat dilakukan dengan Quality Function Deployment (QFD). QFD merupakan metodologi dalam menterjemahkan keinginan dan kebutuhan pelanggan kedalam suatu rancagan produk yang memiliki persyaratan teknis dan karakteristik kualitas tertentu (Noer et al., 2015). Metode QFD tidak hanya mempertimbangkan unsurunsur baik terwujud dan tidak terwujud tetapi juga mengidentifikasi pentingnya masing-masing elemen dalam keputusan.

Konsep QFD pertama kali dikemukaan oleh Yoji Akao di Jepang pada 1972 (Chowdhury \& Quaddus, 2016). Penerapan QFD dapat mengurangi waktu desain sebesar 40\% dan biaya 60\% secara bersamaan dengan dipertahankan dan ditingkatkannya kualitas desain. QFD memungkinkan untuk mengkonversi kebutuhan pelanggan ke dalam produk, jasa, dan fitur baru untuk memikat dan menarik pelanggan baru serta mempertahankan pelanggan lama serta dirancang untuk meningkatkan kepuasan pelanggan dengan meningkatkan kualitas produk dan jasa (Siregar et al., 2017).

Salah satu alat QFD adalah house of quality (HOQ) yang merupakan sebuah teknik grafis untuk mendefinisikan hubungan antara keinginan pelanggan dan produk atau jasa (Hussain et al., 2015). Matrix House of Quality (HoQ) atau rumah mutu adalah bentuk yang paling dikenal dari representasi QFD (Kasan \& Yohanes, 2017). Rumah kualitas tersusun dari tingkat kepentingan oleh konsumen, tingkat kepuasan konsumen, parameter teknis, hubungan atribut kepentingan konsumen dengan parameter teknis, analisis keterkaitan antar parameter teknis, nilai tingkat kepentingan teknis, dan nilai tingkat kepentingan teknis relatif yang dapat dilihat dalam satu skema (Tejedor et al., 2016).

Penggunaan metode QFD dengan alat house of quality telah dilakukan oleh beberapa peneliti sebelumnya untuk menghubungkan antara keinginan pelanggan dengan produk atau jasa. Hasil penelitian pada perusahaan tranportasi bus jalan raya oleh Pakdil \& Kurtulmuşoğlu (2015) menyatakan 7 indikator technical requirements membutuhkan perbaikan. Hasil penelitian yang dilakukan oleh Shrivastava \& Verma (2016) pada sebuah hotel bintang 5 menunjukkan 3 indikator technical requirements membutuhkan perhatian khusus untuk diperbaiki. Cheng et al. (2015) melakukan penelitian pada sebuah restoran kasual mendapatkan hasil 4 indikator technical requirements membutuhkan perbaikan dan penelitian yang dilakukan oleh Tyasdela et al. (2015) menunjukkan bahwa S2 Pizza perlu memberikan perhatian khusus pada 3 indikator technical requirements untuk diperbaiki.

Gerakan revolusi industri 3.0 menjadi industri 4.0 di Indonesia yang dimulai tahun 2011 berdampak pada meningkatnya konektivitas, interaksi, dan batas antara mesin manusia dan sumber daya lainnya semakin berpusat pada teknologi informasi 
dan komunikasi (Sutawidjaya \& Asmarani, 2018). Pranata \& Darma (2014) menyatakan pemanfaatan teknologi yang tepat akan dapat meningkatkan kinerja perusahaan. Salah satu pemanfaat teknologi tersebut adalah e-commerce (Lam \& Dai, 2015) dimana e-commerce adalah perdagangan memakai jaringan komunikasi internet. Masyarakat mulai beralih ke e-commerce karena lebih praktis dan mudah. E-commerce merupakan jawaban atas tuntutan globalisasi dan perusahaan yang masuk ke dalam sistem e-commerce akan dapat meningkatkan keunggulan bersaingnya. Hal ini dikarenakan jangkauan pasar dari e-commerce dapat mencakup nasional maupun internasional (Asmarawati \& Purnomo, 2017). Menurut Dewi (2017), kemajuan sistem e-commerce beriringan dengan meningkatkan kebutuhan akan bisnis jasa pengiriman

Bisnis jasa pengiriman atau kurir per tahunnya diprediksi tumbuh sebesar $15 \%$, hal itu dikarenakan faktor pendukung kegiatan produksi dan konsumsi adalah perusahaan logistik (Valaei et al., 2016). Perusahaan logistik di Indonesia sudah mampu melakukan pengiriman barang dari perkotaan hingga pedesaan, dari sabang hingga Merauke (Dhika et al., 2016). Dikutip dari Lin et al. (2015), konsumen cenderung menuntut jasa kurir perusahaan agar mampu melakukan pengiriman dalam jangka waktu yang pendek dan mempertahankan tingkat layanan yang tinggi.

PT. X merupakan salah satu perusahaan yang bergerak di jasa pengiriman sejak tahun 2004 yang meliputi transportasi udara dan darat. PT. X berkomitmen menjadi partner terpercaya khususnya bagi bisnis online dan e-commerce di seluruh Indonesia. Sesuai dengan komitmennya, PT. X menjanjikan beberapa kelebihan yang menguntungkan bagi online shop seperti layanan pick up paket ke alamat pengirim tanpa minimal nominal paket, pengiriman resi ke nomor penerima melalui sms, timbangan berat yang lebih akurat, pengirim terhindar dari pengiriman paket double, layanan pengiriman regular lebih cepat yaitu satu sampai dua hari, customer service responsif, layanan ganti rugi, sistem pembayaran yang lebih fleksibel, tersedianya software request resi untuk memeriksa status pengiriman serta kerja sama secara kekeluargaan dengan online shop untuk mengatasi masalah pengiriman paket. Meskipun PT. X memberikan jaminan yang dipaparkan di atas, namun keluhan pelanggan terhadap kualitas pelayanan PT. X tetap masih ada. Berdasarkan data yang diperoleh dari mediakonsumen.com, beberapa konsumen mengalami kualitas pelayanan yang buruk atau tidak sesuai janji yang diberikan PT. X., konsumen dilanggar privasinya dengan penyerahan paket bukan ke penerima namun ke orang lain tanpa pemberitahuan dari kurir dan penerimaan paket melebihi batas waktu yang dijanjikan.

\section{METODE PENELITIAN}

Penelitian ini merupakan salah satu bentuk penelitian deskriptif dengan pendekatan kuantitatif. Penelitian dilakukan di PT. X, didasarkan atas beberapa pertimbangan antara lain karena perusahaan ini merupakan perusahaan yang sudah berdiri sejak lama namun kalah saing dengan pendatang baru. Objek penelitian dalam penelitian ini adalah desain kualitas jasa pengiriman PT. X dengan pendekatan house of quality. Populasi dalam penelitian ini adalah konsumen atau pengguna jasa pengiriman PT. X dengan metode purposive sampling sebagai teknik 
pengambilan sampel. Metode pengumpulan data yang digunakan dalam penelitian ini adalah observasi, daftar pertanyaan (kuesioner) dan wawancara.

\section{HASIL DAN PEMBAHASAN}

Jumlah responden dalam penelitian ini adalah 115 orang. Responden yang memberikan tanggapan untuk kuisioner dari penelitian ini telah memenuhi kriteriakriteria yang telah ditetapkan dalam kriteria responden penelitian yaitu berpendidikan terakhir SMA/SMK, sudah menggunakan jasa pengiriman PT. X dan pesaingnya yaitu PT. Ydan PT. Z dalam kurun waktu 6 bulan terakhir. Karakteristik responden dapat dilihat pada Tabel 1.

Tabel 1.

Karakteristik Responden

\begin{tabular}{|c|c|c|c|c|}
\hline No & Variabel & Klasifikasi & Jumlah(Orang) & Presentase (\%) \\
\hline \multirow{5}{*}{1} & \multirow{2}{*}{ Jenis Kelamin } & Laki-Laki & 63 & $54,80 \%$ \\
\hline & & Perempuan & 52 & $45,20 \%$ \\
\hline & \multirow[t]{3}{*}{ Jumlah } & & 115 & \\
\hline & & 18-23 Tahun & 88 & $76.52 \%$ \\
\hline & & 24-29 Tahun & 9 & $7,82 \%$ \\
\hline \multirow[t]{5}{*}{2} & \multirow[t]{3}{*}{ Usia } & 30-35 Tahun & 2 & $1.74 \%$ \\
\hline & & 36-41 Tahun & 6 & $5,22 \%$ \\
\hline & & $\geq 42$ Tahun & 10 & $8,70 \%$ \\
\hline & \multirow[t]{2}{*}{ Jumlah } & & 115 & \\
\hline & & SD & 0 & $0 \%$ \\
\hline \multirow{4}{*}{3} & \multirow{3}{*}{ Pendidikan Terakhir } & SMP/ Sederajat & 0 & $0 \%$ \\
\hline & & SMA/ Sederajat & 10 & $8,70 \%$ \\
\hline & & S1/ Sederajat & 105 & $91,30 \%$ \\
\hline & Jumlah & & 115 & \\
\hline
\end{tabular}

Sumber: Data primer yang diolah, 2020

Berdasarkan Tabel 1. diketahui bahwa responden laki - laki mendominasi dengan 54,80 persen atau 63 orang sedangkan responden wanita sebanyak 53 orang atau 45,30 persen. Responden dengan rentang usia 18-23 tahun mendominasi dengan 76,52 persen atau 88 orang, hal ini memberi gambaran bahwa pengguna jasa ekspedisi PT X, Y dan Z didominasi oleh kalangan remaja akhir dan dewasa awal. Kemudian berdasarkan latar belakang pendidikan, responden didominasi oleh lulusan $\mathrm{S} 1$ /sederajat dengan 91,30 persen atau 115 orang.

Dimensi bukti fisik atau tangible memiliki 5 indikator untuk diukur tingkat kepentingannya melalui penilaian oleh konsumen. Tabel 2. menunjukkan deskripsi jawaban konsumen terhadap dimensi bukti fisik atau tangible. Indikator bukti fisik yang memiliki rata-rata tertinggi adalah indikator fasilitas ruang pelayanan PT. X memadai dengan rata-rata 4,35. Indikator yang memiliki rata-rata terendah dalam dimensi ini adalah kelengakapan informasi yang tercantum di website PT. X dengan rata-rata 3,80 . 
Tabel 2.

Deskripsi Jawaban Responden Terhadap Tingkat Kepentingan pada Dimensi Tangible

\begin{tabular}{|c|c|c|c|c|c|c|c|c|c|}
\hline \multirow[t]{2}{*}{ No } & \multirow[t]{2}{*}{ Pernyataan } & \multicolumn{5}{|c|}{$\begin{array}{c}\text { Proporsi Jawaban } \\
\text { Responden } \\
\text { (orang) }\end{array}$} & \multirow[t]{2}{*}{ Jumlah } & \multirow[t]{2}{*}{ Rerata } & \multirow[t]{2}{*}{ Kriteria } \\
\hline & & 1 & 2 & 3 & 4 & 5 & & & \\
\hline 1 & $\begin{array}{l}\text { Penampilan pegawai PT. X } \\
\text { rapih serta menarik }\end{array}$ & 0 & 0 & 34 & 59 & 22 & 448 & 3.89 & Penting \\
\hline 2 & $\begin{array}{l}\text { Fasilitas ruang pelayanan } \\
\text { memadai. }\end{array}$ & 0 & 0 & 0 & 75 & 40 & 500 & 4.35 & $\begin{array}{l}\text { Sangat } \\
\text { Penting }\end{array}$ \\
\hline 3 & Ruang pelayanan nyaman & 0 & 0 & 15 & 69 & 31 & 476 & 4.14 & Penting \\
\hline 4 & $\begin{array}{l}\text { Mudah mengakses website PT. } \\
\text { X kapan saja }\end{array}$ & 0 & 0 & 17 & 64 & 34 & 477 & 4.15 & Penting \\
\hline 5 & $\begin{array}{l}\text { Informasi yang tercantum di } \\
\text { website PT. X lengkap }\end{array}$ & 0 & 1 & 39 & 57 & 18 & 437 & 3.80 & Penting \\
\hline & Rata-Rata & & & & & & & 4.06 & \\
\hline
\end{tabular}

Sumber: Data primer diolah, 2020

Tingkat kepentingan pada dimensi reliability diukur menggunakan 4 indikator, deskripsi dari jawaban konsumen ditunjukkan Tabel 3. Indikator terpenting menurut konsumen dalam dimensi reliability adalah ketepatan dalam menginput data oleh pegawai dan kesesuaian dengan estimasi waktu yang dijanjikan dengan skor rata-rata yaitu 4,15. Indikator yang memiliki rata-rata terendah dalam dimensi ini yaitu kecepatan pelayanan pegawain dengan skor ratarata yaitu 3,99 .

Tabel 3.

Deskripsi Jawaban Responden Terhadap Tingkat Kepentingan pada Dimensi Reliability

\begin{tabular}{|c|c|c|c|c|c|c|c|c|c|}
\hline \multirow[t]{2}{*}{ No } & \multirow[t]{2}{*}{ Pernyataan } & \multicolumn{5}{|c|}{$\begin{array}{c}\text { Proporsi Jawaban } \\
\text { Responden } \\
\text { (orang) } \\
\end{array}$} & \multirow[t]{2}{*}{ Jumlah } & \multirow[t]{2}{*}{ Rerata } & \multirow[t]{2}{*}{ Kriteria } \\
\hline & & 1 & 2 & 3 & 4 & 5 & & & \\
\hline 1 & Pelayanan pegawai cepat & 0 & 0 & 30 & 56 & 29 & 459 & 3.99 & Penting \\
\hline 2 & $\begin{array}{l}\text { Ketepatan dalam menginput } \\
\text { data oleh pegawai }\end{array}$ & 0 & 0 & 20 & 57 & 38 & 478 & 4.15 & Penting \\
\hline 3 & $\begin{array}{l}\text { Kesesuaian dengan estimasi } \\
\text { waktu yang dijanjikan }\end{array}$ & 0 & 0 & 21 & 56 & 38 & 477 & 4.15 & Penting \\
\hline 4 & Besarnya tarif & 0 & 0 & 26 & 50 & 39 & 473 & 4.11 & Penting \\
\hline & Rata-Rata & & & & & & & 4.10 & \\
\hline
\end{tabular}

Sumber: Data primer diolah, 2020

Dimensi daya tanggap atau responsiveness memiliki 4 indikator yang dinilai tingkat kepentingannya oleh konsumen, sehingga dapat diketahui indikator mana yang memiliki tingkat kepentingan paling tinggi dan yang paling rendah dalam dimensi ini. Deskripsi dari jawaban konsumen ditunjukkan Tabel 4. 
Tabel 4.

Deskripsi Jawaban Responden Terhadap Tingkat Kepentingan pada Dimensi Responsiveness

\begin{tabular}{|c|c|c|c|c|c|c|c|c|c|}
\hline \multirow[t]{2}{*}{ No } & \multirow[t]{2}{*}{ Pernyataan } & \multicolumn{5}{|c|}{$\begin{array}{c}\text { Proporsi Jawaban } \\
\text { Responden } \\
\text { (orang) } \\
\end{array}$} & \multirow[t]{2}{*}{ Jumlah } & \multirow[t]{2}{*}{ Rerata } & \multirow[t]{2}{*}{ Kriteria } \\
\hline & & 1 & 2 & 3 & 4 & 5 & & & \\
\hline 1 & $\begin{array}{l}\text { Pegawai tanggap terhadap } \\
\text { kebutuhan pelanggan }\end{array}$ & 0 & 0 & 36 & 57 & 22 & 446 & 3.88 & Penting \\
\hline 2 & $\begin{array}{l}\text { Petunjuk yang diberikan } \\
\text { oleh pegawai PT. } \mathrm{X}\end{array}$ & 0 & 0 & 46 & 46 & 23 & 437 & 3.80 & Penting \\
\hline 3 & $\begin{array}{l}\text { Kesabaran pegawai PT. X } \\
\text { dalam menanggapi keluhan } \\
\text { pelanggan }\end{array}$ & 0 & 0 & 36 & 57 & 22 & 446 & 3.88 & Penting \\
\hline 4 & $\begin{array}{l}\text { Tanggapan pegawai PT. X } \\
\text { dalam menanggapi keluhan } \\
\text { pelanggan }\end{array}$ & 0 & 0 & 35 & 55 & 25 & 450 & 3.91 & Penting \\
\hline & Rata-Rata & & & & & & & 3.87 & \\
\hline
\end{tabular}

Sumber: Data primer diolah, 2020

Indikator dimensi daya tanggap yang memiliki rata-rata tertinggi yaitu kesigapan pegawai PT. X dalam menanggapi keluhan pelanggan dengan rata-rata sebesar 3.91. Indikator dengan rata-rata terendah yaitu petunjuk yang diberikan oleh pegawai PT. X yang memiliki rata-rata sebesar 3,80.

Tingkat kepentingan pada dimensi assurance diukur menggunakan 4 indikator, deskripsi dari jawaban konsumen ditunjukkan tabel 5. Indikator dengan rata-rata tertinggi adalah pelanggan menerima paket dengan aman dengan rata-rata 4,39 dan indikator yang memiliki rata-rata terendah adalah kepercayaan pelanggan menggunakan jasa PT. X 3,98. Tingginya indicator pelanggan menerima paket dengan aman pada dimensi jaminan (assurance), menandakan pelanggan menganggap bahwa hal terpenting yang perlu dilakukan dalam melakukan jasa ekspedisi adalah pelanggan menerima paket dengan aman.

Tabel 5.

Deskripsi Jawaban Responden Terhadap Tingkat Kepentingan pada Dimensi Assurance

\begin{tabular}{|c|c|c|c|c|c|c|c|c|c|}
\hline \multirow[t]{2}{*}{ No } & \multirow[t]{2}{*}{ Pernyataan } & \multicolumn{5}{|c|}{$\begin{array}{c}\text { Proporsi Jawaban } \\
\text { Responden } \\
\text { (orang) }\end{array}$} & \multirow[t]{2}{*}{ Jumlah } & \multirow[t]{2}{*}{ Rerata } & \multirow[t]{2}{*}{ Kriteria } \\
\hline & & 1 & 2 & 3 & 4 & 5 & & & \\
\hline 1 & $\begin{array}{l}\text { Pelanggan menerima paket } \\
\text { dengan aman }\end{array}$ & 0 & 0 & 7 & 56 & 52 & 505 & 4.39 & $\begin{array}{l}\text { Sangat } \\
\text { Penting }\end{array}$ \\
\hline 2 & $\begin{array}{l}\text { Kepercayaan pelanggan } \\
\text { menggunakan jasa PT. X }\end{array}$ & 0 & 0 & 30 & 57 & 28 & 458 & 3.98 & Penting \\
\hline 3 & Jaminan terhadap kerusakan & 0 & 0 & 14 & 68 & 33 & 479 & 4.16 & Penting \\
\hline 4 & $\begin{array}{l}\text { Jaminan terhadap } \\
\text { kehilangan }\end{array}$ & 0 & 0 & 9 & 66 & 40 & 491 & 4.27 & $\begin{array}{l}\text { Sangat } \\
\text { Penting }\end{array}$ \\
\hline & Rata-Rata & & & & & & & 4.20 & \\
\hline
\end{tabular}

Sumber: Data primer diolah, 2020 
Dimensi empati memiliki 6 indikator yang akan dinilai oleh konsumen untuk melihat tingkat kepentingannya. Deskripsi jawaban konsumen terhadap dimensi empati dapat dilihat pada Tabel 6.

Tabel 6.

Deskripsi Jawaban Responden Terhadap Tingkat Kepentingan pada Dimensi Empathy

\begin{tabular}{|c|c|c|c|c|c|c|c|c|c|}
\hline \multirow{3}{*}{ No } & \multicolumn{9}{|c|}{ Proporsi Jawaban } \\
\hline & \multirow[t]{2}{*}{ Pernyataan } & \multicolumn{5}{|c|}{$\begin{array}{c}\text { Responden } \\
\text { (orang) }\end{array}$} & \multirow[t]{2}{*}{ Jumlah } & \multirow[t]{2}{*}{ Rerata } & \multirow[t]{2}{*}{ Kriteria } \\
\hline & & 1 & 2 & 3 & 4 & 5 & & & \\
\hline 1 & $\begin{array}{l}\text { Pegawai bersikap ramah } \\
\text { terhadap pelanggan }\end{array}$ & 0 & 1 & 30 & 58 & 26 & 454 & 3.95 & Penting \\
\hline 2 & $\begin{array}{l}\text { Pegawai sopan dalam } \\
\text { bersikap terhadap pelanggan }\end{array}$ & 0 & 0 & 25 & 66 & 24 & 459 & 3.99 & Penting \\
\hline 3 & $\begin{array}{l}\text { Pegawai cepat dalam } \\
\text { memberikan solusi atas } \\
\text { keluhan yang pelanggan } \\
\text { ajukan }\end{array}$ & 0 & 0 & 35 & 56 & 24 & 449 & 3.90 & Penting \\
\hline 4 & $\begin{array}{l}\text { Perlakuan yang adil } \\
\text { terhadap pelanggan }\end{array}$ & 0 & 1 & 32 & 57 & 25 & 451 & 3.92 & Penting \\
\hline 5 & $\begin{array}{l}\text { Pegawai mengenal nama } \\
\text { pelanggan }\end{array}$ & 0 & 4 & 50 & 44 & 17 & 419 & 3.64 & Penting \\
\hline 6 & $\begin{array}{l}\text { Kurir mengetahui alamat } \\
\text { pelanggan dengan baik }\end{array}$ & 0 & 0 & 10 & 59 & 46 & 496 & 4.31 & $\begin{array}{l}\text { Sangat } \\
\text { Penting }\end{array}$ \\
\hline & Rata-Rata & & & & & & & 3.95 & \\
\hline
\end{tabular}

Sumber: Data primer diolah, 2020

Indikator yang memiliki rata-rata tertinggi adalah kurir mengetahui alamat pelanggan dengan baik dengan rata-rata sebesar 4,31 dan indikator yang memiliki rata-rata terendah yaitu pegawai mengenal nama pelanggan dengan nilai rata-rata 3,64 . Nilai ini termasuk dalam kategori penting namun dibanding dengan nilai ratarata indikator lainnya indikator ini memperoleh nilai lebih kecil, indikator tersebut adalah pegawai mengenal nama pelanggan (empathy). Hal ini berarti pelanggan menggangap pegawai mengenal nama pelanggan tidak sepenting indikator lainnya untuk diterapkan.

Tingkat kinerja perusahaan pada dimensi bukti fisik atau tangible memiliki 5 indikator. Tabel 7. menunjukkan deskripsi jawaban responden terhadap dimensi bukti fisik atau tangible. Pada dimensi empati, indikator yang memiliki rata-rata tingkat kinerja tertinggi adalah fasilitas ruang pelayanan memadai sebesar 3,89. Indikator dengan rata-rata tingkat kinerja terendah adalah penampilan pegawai PT. $\mathrm{X}$ rapih serta menarik dengan rata-rata sebesar 3.79. 
Tabel 7.

Deskripsi Jawaban Responden Terhadap Tingkat Kinerja Perusahaan pada Dimensi Tangible

\begin{tabular}{|c|c|c|c|c|c|c|c|c|c|}
\hline \multirow{3}{*}{ No } & \multicolumn{9}{|c|}{ Proporsi Jawaban } \\
\hline & \multirow[t]{2}{*}{ Pernyataan } & \multicolumn{5}{|c|}{$\begin{array}{c}\text { Responden } \\
\text { (orang) }\end{array}$} & \multirow[t]{2}{*}{ Jumlah } & \multirow[t]{2}{*}{ Rerata } & \multirow[t]{2}{*}{ Kriteria } \\
\hline & & 1 & 2 & 3 & 4 & 5 & & & \\
\hline 1 & $\begin{array}{l}\text { Penampilan pegawai PT. X } \\
\text { rapih serta menarik }\end{array}$ & 1 & 2 & 37 & 55 & 20 & 436 & 3.79 & Setuju \\
\hline 2 & $\begin{array}{l}\text { Fasilitas ruang pelayanan } \\
\text { memadai }\end{array}$ & 0 & 1 & 35 & 55 & 24 & 447 & 3.89 & Setuju \\
\hline 3 & Ruang pelayanan nyaman & 0 & 3 & 33 & 58 & 21 & 442 & 3.84 & Setuju \\
\hline 4 & $\begin{array}{l}\text { Mudah mengakses website } \\
\text { PT. X kapan saja }\end{array}$ & 2 & 3 & 29 & 57 & 24 & 443 & 3.85 & Setuju \\
\hline 5 & $\begin{array}{l}\text { Informasi yang tercantum di } \\
\text { website PT. X lengkap }\end{array}$ & 0 & 2 & 34 & 56 & 23 & 445 & 3.87 & Setuju \\
\hline & & $\mathrm{a}-\mathrm{rc}_{\mathrm{c}}$ & & & & & & 3.85 & \\
\hline
\end{tabular}

Sumber: Data primer diolah, 2020

Tingkat kinerja perusahaan pada dimensi reliability diukur dengan 4 indikator untuk mengetahui seberapa kinerja perusahaan sudah dilakukan untuk memenuhi keinginan konsumen. Deskripsi jawaban konsumen terhadap dimensi reliability dapat dilihat pada Tabel 8. Indikator dengan rata-rata tingkat kinerja tertinggi adalah kesesuaian dengan estimasi waktu yang dijanjikan dengan rata-rata sebesar 4,28 . Indikator dengan rata-rata terendah yaitu pelayanan pegawai cepat dengan rata-rata sebesar 3,89 .

Tabel 8.

Deskripsi Jawaban Responden Terhadap Tingkat Kinerja Perusahaan pada Dimensi Reliability

\begin{tabular}{|c|c|c|c|c|c|c|c|c|c|}
\hline \multirow[t]{2}{*}{ No } & \multirow[t]{2}{*}{ Pernyataan } & \multicolumn{5}{|c|}{$\begin{array}{c}\text { Proporsi Jawaban } \\
\text { Responden } \\
\text { (orang) }\end{array}$} & \multirow[t]{2}{*}{ Jumlah } & \multirow[t]{2}{*}{ Rerata } & \multirow[t]{2}{*}{ Kriteria } \\
\hline & & 1 & 2 & 3 & 4 & 5 & & & \\
\hline 1 & Pelayanan pegawai cepat & 0 & 2 & 34 & 54 & 25 & 447 & 3.89 & Setuju \\
\hline 2 & $\begin{array}{l}\text { Ketepatan dalam menginput } \\
\text { data oleh pegawai }\end{array}$ & 0 & 0 & 26 & 65 & 24 & 458 & 3.98 & Setuju \\
\hline 3 & $\begin{array}{l}\text { Kesesuaian dengan estimasi } \\
\text { waktu yang dijanjikan }\end{array}$ & 0 & 0 & 12 & 59 & 44 & 492 & 4.28 & $\begin{array}{l}\text { Sangat } \\
\text { Setuju }\end{array}$ \\
\hline \multirow[t]{2}{*}{4} & Besarnya tarif & 0 & 0 & 17 & 65 & 33 & 476 & 4.14 & Setuju \\
\hline & \multicolumn{6}{|c|}{ Rata-rata } & & 4.07 & \\
\hline
\end{tabular}

Sumber: Data primer diolah, 2020

Dimensi daya tanggap atau responsiveness memiliki 3 indikator yang dinilai kinerjanya oleh pelanggan sehingga dapat mengetahui indikator mana yang memiliki kinerja terendah. Tabel 9. menunjukkan deskripsi jawaban pelanggan terhadap dimensi daya tanggap atau responsiveness Indikator yang miliki kinerja tertinggi dalam dimensi daya tanggap atau responsiveness adalah tanggapan pegawai PT. X dalam menanggapi keluhan pelanggan dengan rata-rata sebesar 
3.91. Indikator dengan rata-rata terendah yaitu petunjuk yang diberikan oleh pegawai PT. X dengan nilai rata-ratanya adalah 3,77.

Tabel 9.

Deskripsi Jawaban Responden Terhadap Tingkat Kinerja Perusahaan pada Dimensi Responsiveness

\begin{tabular}{|c|c|c|c|c|c|c|c|c|c|}
\hline \multirow{3}{*}{ No } & \multirow{3}{*}{ Pernyataan } & \multirow{2}{*}{\multicolumn{5}{|c|}{$\begin{array}{c}\text { Proporsi Jawaban } \\
\text { Responden } \\
\text { (orang) } \\
\end{array}$}} & \multirow{3}{*}{ Jumlah } & \multirow{3}{*}{ Rerata } & \multirow{3}{*}{ Kriteria } \\
\hline & & & & & & & & & \\
\hline & & 1 & 2 & 3 & 4 & 5 & & & \\
\hline 1 & $\begin{array}{l}\text { Pegawai tanggap terhadap } \\
\text { kebutuhan pelanggan }\end{array}$ & 0 & 0 & 36 & 57 & 22 & 446 & 3.88 & Setuju \\
\hline 2 & $\begin{array}{l}\text { Petunjuk yang diberikan } \\
\text { oleh pegawai PT. } X\end{array}$ & 0 & 2 & 43 & 49 & 21 & 434 & 3.77 & Setuju \\
\hline 3 & $\begin{array}{l}\text { Kesabaran pegawai PT. X } \\
\text { dalam menanggapi keluhan } \\
\text { pelanggan }\end{array}$ & 0 & 0 & 36 & 57 & 22 & 446 & 3.88 & Setuju \\
\hline 4 & $\begin{array}{l}\text { Tanggapan pegawai PT. X } \\
\text { dalam menanggapi keluhan } \\
\text { pelanggan }\end{array}$ & 0 & 0 & 35 & 55 & 25 & 450 & 3.91 & Setuju \\
\hline & Rat & & & & & & & 3.86 & \\
\hline
\end{tabular}

Sumber: Data primer diolah, 2020

Indikator jaminan atau assurance memiliki 4 indikator yang dinilai tingkat kinerjanya oleh pelanggan. Tabel 10. menunjukkan deskripsi jawaban pelanggan terhadap dimensi jaminan atau assurance. Indikator pada dimensi jaminan yang tertinggi yaitu kepercayaan pelanggan dengan rata-rata sebesar 4,03. Indikator yang memiliki rata-rata terendah adalah pelanggan menerima paket dengan aman dengan rata-rata sebesar 3,84 .

Tabel 10.

Deskripsi Jawaban Responden Terhadap Tingkat Kinerja Perusahaan pada Dimensi Assurance

\begin{tabular}{|c|c|c|c|c|c|c|c|c|c|}
\hline \multirow[t]{2}{*}{ No } & \multirow[t]{2}{*}{ Pernyataan } & \multicolumn{5}{|c|}{$\begin{array}{c}\text { Proporsi Jawaban } \\
\text { Responden } \\
\text { (orang) }\end{array}$} & \multirow[t]{2}{*}{ Jumlah } & \multirow[t]{2}{*}{ Rerata } & \multirow[t]{2}{*}{ Kriteria } \\
\hline & & 1 & 2 & 3 & 4 & 5 & & & \\
\hline 1 & $\begin{array}{l}\text { Pelanggan menerima paket } \\
\text { dengan aman }\end{array}$ & 0 & 3 & 33 & 58 & 21 & 442 & 3.84 & Setuju \\
\hline 2 & Kepercayaan pelanggan & 0 & 0 & 24 & 64 & 27 & 463 & 4.03 & Setuju \\
\hline 3 & Jaminan terhadap kerusakan & 0 & 0 & 29 & 62 & 24 & 455 & 3.96 & Setuju \\
\hline 4 & Jaminan terhadap kehilangan & 0 & 0 & 28 & 58 & 29 & 461 & 4.01 & Setuju \\
\hline & $\mathrm{Ra}$ & a-ra & & & & & & 3.96 & \\
\hline
\end{tabular}

Sumber: Data primer diolah, 2020

Dimensi empati atau empathy memiliki 4 indikator yang dinilai tingkat kinerjanya oleh pelanggan, sehingga dapat dilihat indikator mana yang memerlukan perbaikan dalam kinerjanya. Tabel 11. menunjukkan deskripsi jawaban konsumen terhadap dimensi empati. 
Tabel 11.

Deskripsi Jawaban Responden Terhadap Tingkat Kinerja Perusahaan pada Dimensi Empathy

\begin{tabular}{|c|c|c|c|c|c|c|c|c|c|}
\hline \multirow[t]{2}{*}{ No } & \multirow[t]{2}{*}{ Pernyataan } & \multicolumn{5}{|c|}{$\begin{array}{c}\text { Proporsi Jawaban } \\
\text { Responden } \\
\text { (orang) }\end{array}$} & \multirow[t]{2}{*}{ Jumlah } & \multirow[t]{2}{*}{ Rerata } & \multirow[t]{2}{*}{ Kriteria } \\
\hline & & 1 & 2 & 3 & 4 & 5 & & & \\
\hline 1 & $\begin{array}{ll}\text { Pegawai bersikap } & \text { ramah } \\
\text { terhadap pelanggan } & \end{array}$ & 0 & 2 & 40 & 50 & 23 & 439 & 3.82 & Setuju \\
\hline 2 & $\begin{array}{l}\text { Pegawai sopan dalam } \\
\text { bersikap terhadap pelanggan }\end{array}$ & 0 & 3 & 28 & 59 & 25 & 451 & 3.92 & Setuju \\
\hline 3 & $\begin{array}{l}\text { Pegawai cepat dalam } \\
\text { memberikan solusi atas } \\
\text { keluhan yang pelanggan } \\
\text { ajukan }\end{array}$ & 0 & 2 & 34 & 59 & 20 & 442 & 3.84 & Setuju \\
\hline 4 & $\begin{array}{l}\text { Perlakuan yang adil terhadap } \\
\text { pelanggan }\end{array}$ & 0 & 3 & 32 & 54 & 26 & 448 & 3.89 & Setuju \\
\hline 5 & $\begin{array}{l}\text { Pegawai mengenal nama } \\
\text { pelanggan }\end{array}$ & 13 & 27 & 41 & 25 & 9 & 335 & 2.91 & Netral \\
\hline 6 & $\begin{array}{l}\text { Kurir mengetahui alamat } \\
\text { pelanggan dengan baik }\end{array}$ & 1 & 1 & 26 & 47 & 40 & 469 & 4.08 & Setuju \\
\hline & & a-rat & & & & & & 3.74 & \\
\hline
\end{tabular}

Sumber: Data primer diolah, 2020

Indikator yang memiliki rata-rata tertinggi adalah indikator yang memperoleh nilai rata-rata 4.08 yaitu pengetahuan kurir yang memadai tentang alamat pengiriman. Indikator yang memiliki rata-rata terendah adalah indikator yang memperoleh nilai rata-rata 2,91, nilai ini termasuk dalam golongan netral, namun dibanding dengan nilai rata-rata indikator lainnya, indikator ini memperoleh nilai lebih kecil, indikator tersebut adalah pegawai mengenal nama pelanggan yaitu pada dimensi empati. Hal ini berarti pelanggan merasa bahwa PT. X belum mampu memenuhi harapan konsumen dalam hal pegawainya mengenal nama pelanggan.

Tabel 12 berikut menunjukkan bahwa dimensi assurance menempati rata-rata tingkat kepentingan paling tinggi yaitu sebesar 4.20, sementara dimensi dengann rata-rata paling kecil adalah dimensi responsiveness yaitu sebesar 3,87 .

Tabel 12.

Rata-Rata Tingkat Kepentingan Konsumen

\begin{tabular}{lcc}
\hline & Dimensi & Rata-Rata \\
\hline Tangibles & 4,06 \\
Reliability & 4,10 \\
Responsiveness & 3,87 \\
Assurance & 4,20 \\
Empathy & 3,95 \\
\hline Jumlah & 4,04 \\
\hline
\end{tabular}

Sumber: Data primer diolah, 2020

Tabel 13. menunjukkan rata-rata tingkat performance dimensi kualitas pelayanan. Dimensi dengan rata-rata tertinggi yaitu dimensi reliability yaitu dengan 
rata-rata 4.07, sementara dimensi dengan rata-rata terendah yaitu dimensi empathy 3,74 .

Tabel 13.

Rata-Rata Tingkat Performance Dimensi Kualitas Pelayanan

\begin{tabular}{lcc}
\hline & Dimensi & Rata-Rata \\
\hline Tangibles & 3,85 \\
Reliability & 4.07 \\
Responsiveness & 3.86 \\
Assurance & 3.96 \\
Empathy & 3.74 \\
\hline Jumlah & 3,90 \\
\hline
\end{tabular}

Sumber: Data primer diolah, 2020

Tahap berikutnya adalah menganalisis solusi-solusi untuk memenuhi keinginan pelanggan untuk dapat memenuhi kepuasan pelanggan. Solusi tersebut berupa respon teknis. Respon teknis (Technical Response atau Technical Requirement) adalah penterjemahan dari suara konsumen kedalam bahasa perusahaan atau organisasi (Hartanti et al., 2015). Hubungan antara kebutuhan pelanggan dan persyaratan teknis dan dampak dari hubungan ini dapat diberikan pada level setinggi (5), sedang (3) dan rendah (1), penilaian dengan menggunakan bobot tersebut juga digunakan dalam penelitian oleh Kelesbayev et al., (2016), Chen (2016), dan Escola (2018)

Tabel 14.

Technical Requirement (TR)

\begin{tabular}{lll}
\hline No & & Technical Requirement \\
\hline 1 & Kualitas SDM & \\
2 & Ketersediaan SDM & \\
3 & Ketersediaan modal kerja & \\
4 & Ketersediaan modal tetap & \\
5 & Peralatan kantor \\
6 & Pelatihan SDM \\
7 & Prosedur sistem yang jelas \\
Sumber: Data primer diolah, 2020
\end{tabular}

Kualitas SDM yang dimaksud adalah mampu melayani dengan cepat dan tepat serta memiliki karakter ramah, sopan, mau belajar, jujur, dan bekerja keras, serta berintegritas terhadap pekerjaan. Menurut pihak PT. X beberapa pegawai belum mencapai target dalam bekerja keras dan berkarakter ramah sehingga mendapat skor 4 sedangkan targetnya adalah 5. Ketersediaan SDM yang dimaksud adalah jumlah SDM yang ada, 1 kepala cabang daerah Bali, 1 kepala kurir, 1 admin (keuangan), 4 customer service, 1 inputer, 3 supir, 26 kurir. Menurut pihak PT. X permintaan yang tinggi pada saat akhir tahun dan Hari Belanja Nasional menyebabkan kekurangan kurir sehingga mendapat skor 3.

Ketersediaan modal kerja yang dimaksud adalah kas cukup untuk kegiatan ekspedisi sehari-hari contohnya untuk bensin kendaraan, supply alat tulis, selotip, stapler, dan lain-lain. Menurut pihak PT. X, kas untuk kegiatan ekspedisi harus 
ditingkatkan dan menyiapkan dana cadangan untuk operasional sehingga mendapatkan skor 4 sedangkan targetnya adalah 5. Ketersediaan modal tetap yang dimaksud adalah 4 mobil, motor sesuai jumlah kurir, dan gaji pegawai. Menurut pihak PT. X jumlah motor bisa ditambahkan sehingga jika ada motor yang bermasalah kegiatan ekspedisi tidak terhambat sehingga skor yang diberikan untuk respon ini adalah 4

Peralatan kantor yang dimaksud adalah minimal tersedia 1 timbangan digital disertai kamera, 6 meja dan kursi, 6 komputer, 5 smartphone, 1 printer, barcode scanner, 5 rak untuk menyimpan paket, 1 wood cutter machine, 1 hand pallet, dan wifi. Menurut pihak PT. X peralatan kantor sudah baik namun kualitas yang lebih baik akan mempermudah kegiatan ekspedisi sehingga mendapat skor 4.

Pelatihan SDM yang dimaksud untuk menjamin kualitas servis pelatihan training (pengenalan wilayah dan manner) yang dilatih dan diawasi langsung selama 3 bulan atau sampai paham. Menurut pihak PT. X pelatihan SDM membutuhkan evaluasi secara berkala sehingga jika ada yang belum terpenuhi dapat dilakukan pelatihan ulang sehingga mendapat skor 3 .

Prosedur sistem yang dimaksud dijabarkan pada tabel 15. Menurut pihak PT. $\mathrm{X}$ prosedur sistem sudah jelas dan berjalan dengan baik sehingga mendapat skor 5 jika diukur dengan skala likert 1-5.

Table 15.

Prosedur sistem yang jelas di PT X

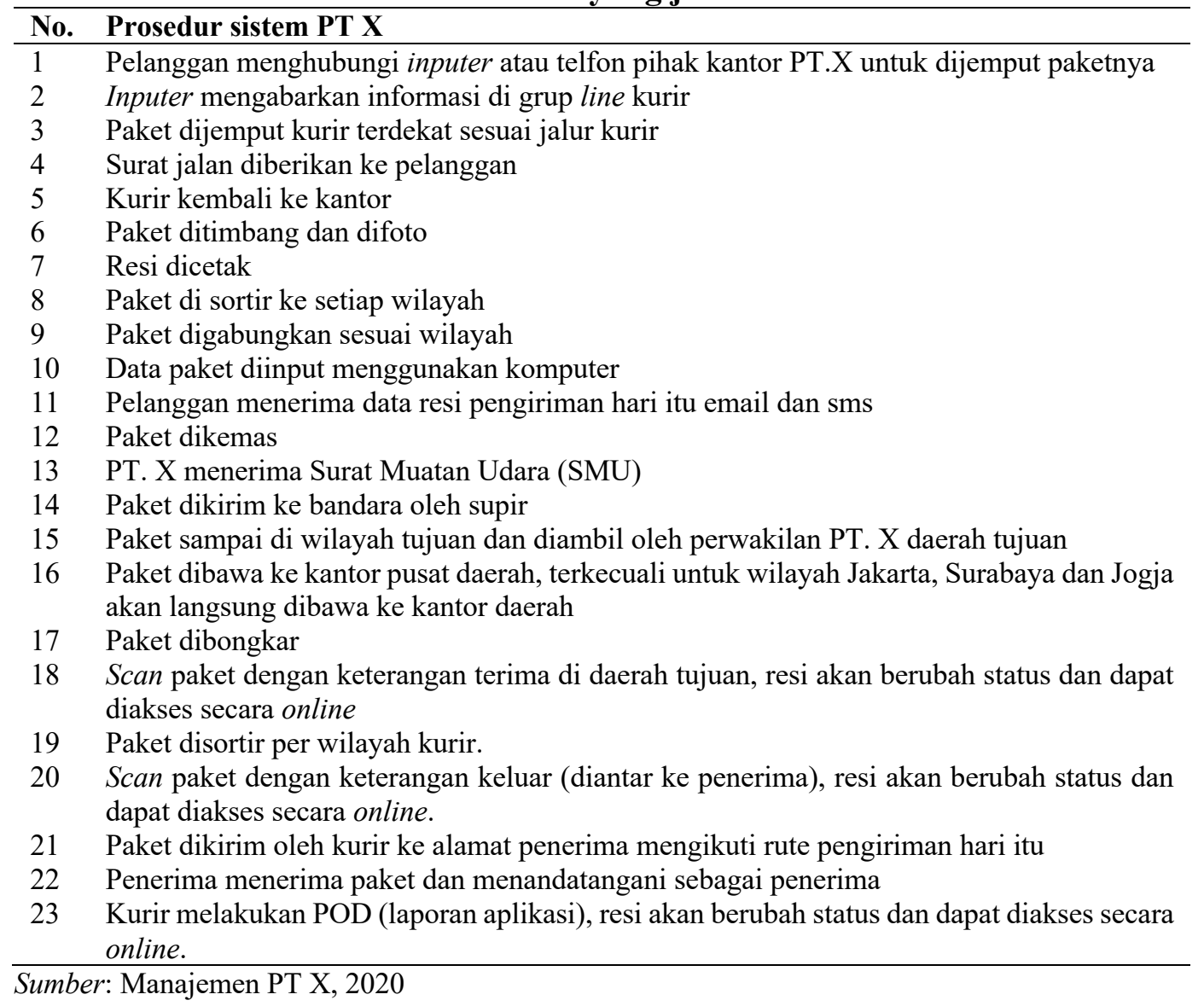


Tahap berikutnya ialah analisis Intercorrelation Matrix diantara TR bertujuan untuk mengetahui hubungan atribut-atribut dalam TR. Bagian ini menunjukkan interaksi antara karakteristik teknik (Technical response / Technical Requirement). Bentuk korelasi teknis tersebut berupa matriks yang menyerupai atap, sehingga sering disebut Roof Matrix. Korelasi ini penting untuk diidentifikasi agar perusahaan mengetahui karakteristik apa saja yang menjadi prioritas tanpa harus mengabaikan karakteristik teknis lain yang mendukungnya (Suryopratomo, 2019).

Tujuan dari langkah ini adalah untuk memberikan kualitas layanan yang lebih baik dalam persaingan yang mana perbandingan dilakukan dalam persaingan tersebut (Bajčetić et al., 2018). Kolom ini juga menunjukkan bagaimana pengetahuan penelitian pasar mengenai urutan kompetitor memuaskan keinginan pelanggan.

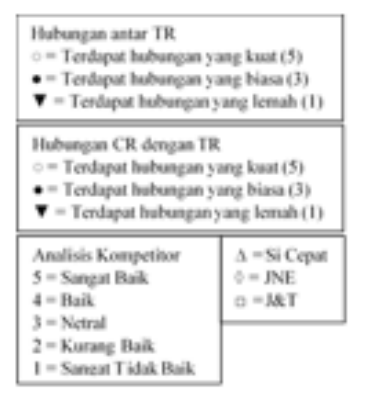

\begin{tabular}{|c|c|c|c|c|c|c|c|c|c|c|c|}
\hline \multirow[b]{2}{*}{ Texgibles: } & \multirow[t]{2}{*}{14} & \multirow{2}{*}{ in } & \multirow{2}{*}{ 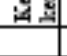 } & \multirow{2}{*}{2} & \multirow[t]{2}{*}{ מ } & \multirow[t]{2}{*}{ 点江 } & \multirow[t]{2}{*}{ ش } & \multicolumn{4}{|c|}{ 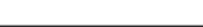 } \\
\hline & & & & & & & & 1 & 2 & 4 & 5 \\
\hline - Denampilan gegawai Si Cepat ragih nerta menarik & $\mathbf{T}$ & & * & & & & $=$ & & & $\Delta 0$ & D \\
\hline - Farilitar rang pelayman menedai & & & * & $\boldsymbol{*}$ & $=$ & & & & & مـ & 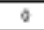 \\
\hline - R.earg pelayanan zyamen & & & $\cdot$ & + & $=$ & & & & & so & D \\
\hline - Mudah nengakaza webrits Si Copat kapun 1aja & $=$ & $=$ & $\dot{*}$ & & & & & & & a & 0 \\
\hline - Informaxi yang tercantum de webrita Si Cepat lengksp & & & & & & * & & & & $\Delta 0$ a & \\
\hline \multicolumn{12}{|l|}{ Rrliabliigy : } \\
\hline - Deligyzan pegauri espat & $\cdot$ & • & & & & $=$ & $=$ & & & مصة & 0 \\
\hline - Retopatan dalam mengingut datz oleh pagawai & $\cdot$ & & & & & & $=$ & & & $\Delta$ & 2 \\
\hline - Rerevuzian dengan ertimaxi walta yang dijenjikan & $*$ & & & & $=$ & $*$ & $=$ & & & 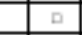 & so \\
\hline - Benzryz tzeif & & & & $=$ & $=$ & $\mathbf{\nabla}$ & $\boldsymbol{*}$ & & & DOA & \\
\hline \multicolumn{12}{|l|}{ Frypousiviman: } \\
\hline Degawai tangerp terhadap ketutulen pelenggen & $=$ & $=$ & & & & & $=$ & & & $\Delta \mathrm{A}$ & D \\
\hline Detajulk yang diberiban aleh pegawai Si Cepat & $=$ & • & & & & * & $=$ & & & so & D \\
\hline 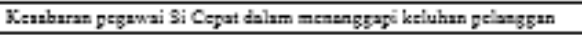 & $=$ & & & & $\boldsymbol{\nabla}$ & & $=$ & & & ما & 2 \\
\hline 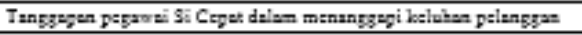 & $=$ & & & & $\boldsymbol{\nabla}$ & & $=$ & & & a & 2 \\
\hline \multicolumn{12}{|l|}{ Asruraser: : } \\
\hline Delanggen menerima paket dengen amen & $=$ & $\cdot$ & & $=$ & - & $=$ & $=$ & & & & 30 ב \\
\hline Xeperexyazn pelanggan mengg-nekan jas Si Cepat & $=$ & $\cdot$ & & $=$ & & $=$ & $=$ & & & so & $\mathrm{D}$ \\
\hline Jeminan tsthodeg kerusakan & & & $=$ & & & + & & & & $\mathrm{ad}$ & 2 \\
\hline Jaminen terhedeg behilangen & & & $=$ & & & + & & & & $2 \mathrm{sA}$ & \\
\hline \multicolumn{12}{|l|}{ Inepaty : } \\
\hline Degawai berrikgy ramah tehalap pelonggan & $=$ & $\mathbf{T}$ & & & & & $=$ & & & مصة & 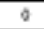 \\
\hline Degawai aopan dalem berriksg terhadeg pelenggen & $=$ & & & & & & $=$ & & & so & D \\
\hline 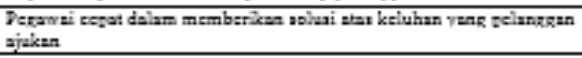 & $=$ & & & & & & $=$ & & & مـ & • \\
\hline Derlakuan yaag adil terhedeg pelanggen & $=$ & & & & & & $=$ & & & مـ & 0 \\
\hline Degawai mengenal nama pelanggan & $=$ & & & & & & $=$ & & $\Delta$ & $\infty$ & \\
\hline Xetir mengetahei alamat pelanggen dengen baik & $=$ & & & & & & $=$ & & & DOA & \\
\hline Deringlat Kepentingan & 157795 & 85.88 & 20.75 & 12530 & 88.95 & 541.35 & 961.81 & & & & \\
\hline Nilai Tarģat (Atribut Teknia) & 5 & 3 & 5 & 5 & 5 & 5 & 5 & & & & \\
\hline \multirow[t]{2}{*}{ Evalusui Tckanir } & 4 & 2 & 4 & 4 & 4 & 5 & 3 & & & & \\
\hline & 4 & 4 & 5 & 4 & 4 & 5 & 4 & & & & \\
\hline
\end{tabular}

Gambar 1. House of Quality 
Tabel 16.

Penilaian terhadap Kompetitor

\begin{tabular}{|c|c|c|c|c|c|c|}
\hline No & Customer Requirement & 1 & 2 & 3 & 4 & 5 \\
\hline 1 & Penampilan pegawai PT. X rapih serta menarik & & & & $\Delta \diamond$ & $\square$ \\
\hline 2 & Fasilitas ruang pelayanan memadai & & & & $\Delta \square$ & $\diamond$ \\
\hline 3 & Ruang pelayanan nyaman & & & & $\Delta \diamond$ & $\square$ \\
\hline 4 & Mudah mengakses website PT. X kapan saja & & & & $\Delta \square$ & $\diamond$ \\
\hline 5 & Informasi yang tercantum di website PT. X lengkap & & & & $\Delta \square_{\square}$ & \\
\hline 6 & Pelayanan pegawai cepat & & & & $\Delta \square$ & $\diamond$ \\
\hline 7 & Ketepatan dalam menginput data oleh pegawai & & & & $\Delta \square$ & $\diamond$ \\
\hline 8 & Kesesuaian dengan estimasi waktu yang dijanjikan & & & & $\square$ & $\Delta \diamond$ \\
\hline 9 & Besarnya tarif & & & & $\square \diamond \Delta$ & \\
\hline 10 & Pegawai tanggap terhadap kebutuhan pelanggan & & & & $\diamond \Delta$ & $\square$ \\
\hline 11 & Petunjuk yang diberikan oleh pegawai PT. X & & & & $\Delta \diamond$ & $\square$ \\
\hline 12 & $\begin{array}{l}\text { Kesabaran pegawai PT. X dalam menanggapi keluhan } \\
\text { pelanggan }\end{array}$ & & & & $\Delta \square$ & $\diamond$ \\
\hline 13 & $\begin{array}{l}\text { Tanggapan pegawai PT. X dalam menanggapi keluhan } \\
\text { pelanggan }\end{array}$ & & & & $\Delta \square$ & $\diamond$ \\
\hline 14 & Pelanggan menerima paket dengan aman & & & & & $\Delta \diamond_{\square}$ \\
\hline 15 & Kepercayaan pelanggan menggunakan jasa PT. X & & & & $\Delta \diamond$ & $\square$ \\
\hline 16 & Jaminan terhadap kerusakan & & & & $\square \Delta$ & $\diamond$ \\
\hline 17 & Jaminan terhadap kehilangan & & & & $\diamond \square \Delta$ & \\
\hline 18 & Pegawai bersikap ramah terhadap pelanggan & & & & $\Delta \square$ & $\diamond$ \\
\hline 19 & Pegawai sopan dalam bersikap terhadap pelanggan & & & & $\Delta \diamond$ & $\square$ \\
\hline 20 & $\begin{array}{l}\text { Pegawai cepat dalam memberikan solusi atas keluhan } \\
\text { yang pelanggan ajukan }\end{array}$ & & & & $\Delta \square$ & $\diamond$ \\
\hline 21 & Perlakuan yang adil terhadap pelanggan & & & & $\Delta \square$ & $\diamond$ \\
\hline 22 & Pegawai mengenal nama pelanggan & & $\Delta$ & & $\square \diamond$ & \\
\hline 23 & Kurir mengetahui alamat pelanggan dengan baik & & & & $\square \diamond \Delta$ & \\
\hline
\end{tabular}

Sumber: Data primer yang diolah, 2020

Tabel 16. menunjukkan bahwa PT. X mendapat penilaian Sangat Baik (5) sebanyak 2 indikator, penilaian Baik (4) sebanyak 20 indikator, penilaian Kurang Baik (2) sebanyak 1 indikator sementara PT. Y mendapat penilaian Sangat Baik (5) sebanyak 12 indikator, penilaian Baik (4) sebanyak 11 indikator, sementara PT. Z mendapat penilaian Sangat Baik (5) sebanyak 7 indikator, penilaian Baik (4) sebanyak 16 indikator. Dapat dilihat bahwa PT. X mendapat penilaian Sangat Baik (5) lebih sedikit dari kompetitornya dalam usaha ekspedisi.

Kualitas SDM PT. X dan pesaingnya yaitu PT. Y dan PT. Z yang dimaksud adalah mampu melayani dengan cepat dan tepat serta memiliki karakter ramah, sopan, mau belajar, jujur, dan bekerja keras, serta berintegritas terhadap pekerjaan. Ketersediaan SDM PT. X yang dimaksud adalah 1 kepala cabang daerah Bali, 1 kepala kurir, 1 admin (keuangan), 4 customer service, 1 inputer, 3 supir, 26 kurir, helper. PT. Y membutuhkan 32 kurir dan 4 supir. PT. Z membutuhkan 35 kurir dan 4 supir.

Ketersediaan modal kerja PT. X yang dimaksud adalah kas cukup atau melebihi untuk kegiatan ekspedisi sehari-hari contohnya untuk bensin kendaraan, supply alat tulis, selotip, stapler, dan lain-lain. Pesaingnya PT. Y dan PT. Z kesediaan kasnya lebih dari cukup. Ketersediaan modal tetap PT. X dan kedua pesaingnya yang dimaksud adalah 4 mobil, motor sesuai jumlah kurir, dan gaji pegawai. Sedangkan PT. Y dan PT. Z adalah 6 mobil. Peralatan kantor PT. X dan 
pesaingnya yang dimaksud adalah minimal tersedia 1 timbangan digital disertai kamera, 6 meja dan kursi, 6 komputer, 5 smartphone, 1 printer, barcode scanner, 5 rak untuk menyimpan paket, 1 wood cutter machine, 1 hand pallet, dan wifi.

Prosedur sistem PT X yang dimaksud dijabarkan pada tabel 15. PT. Y dan PT. Z memiliki prosedur sistem yang sama namun berbeda pada langkah ke-16. PT. Y membawa paket ke kantor pusat daerah, terkecuali untuk wilayah Jakarta, Surabaya, Jogja, Medan, Bekasi, Palembang, Bandung, Makassar, dan Pontianak akan langsung dibawa ke kantor daerah. PT. Z membawa paket ke kantor pusat daerah, terkecuali untuk wilayah Jakarta, Surabaya, Jogja, Medan, Bekasi, dan Bandung akan langsung dibawa ke kantor daerah.

Pelatihan SDM PT. X yang dimaksud adalah pelatihan pengenalan wilayah dan manner yang dilatih dan diawasi langsung selama 3 bulan atau sampai paham. Sedangkan PT. Y adalah diadakan pelatihan SDM selama 3 bulan, percobaan selama 1 bulan dan evaluasi kinerja SDM sebulan sekali, dan PT. Z adalah pelatihan SDM selama 2 bulan, percobaan selama 1 bulan.

PT. X masih tertinggal jika dibandingkan dengan kompetitornya. Jumlah supir dan kurir lebih sedikit dibanding kompetitornya, peralatan dan mesin yang lebih banyak, modal kerja PT. X cukup sedangkan PT. Y dan PT. Z melebihi cukup, jumlah mobil lebih sedikit dibandingkan kompetitornya. Pelayanan yang diberikan oleh PT. X belum dapat memenuhi keinginan konsumen atau dalam kata lain belum optimal dilihat dari adanya gap antara kepentingan konsumen dengan tingkat kinerja perusahaan. Dilihat dari tabel rata-rata tingkat kepentingan adalah 4,04 sementara rata-rata tingkat kinerja adalah 3,89 yang menunjukkan bahwa kinerja perusahaan belum mampu untuk memenuhi keinginan konsumen.

Hubungan sangat kuat antara CR dan TR disimbolkan dengan " $O$ " yang berarti CR sangat terpengaruhi oleh TR seperti yang dijabarkan pada Tabel 17.

Tabel 17.

\section{Hubungan sangat kuat antara CR dan TR}

\begin{tabular}{|c|c|}
\hline No. & Hubungan CR dan TR \\
\hline 1 & $\begin{array}{l}\text { Penampilan pegawai PT. X rapih serta menarik memiliki hubungan kuat dengan Pelatihan } \\
\text { SDM }\end{array}$ \\
\hline 2 & Fasilitas ruang pelayanan memadai memiliki hubungan kuat dengan peralatan kantor \\
\hline 3 & $\begin{array}{l}\text { Ruang pelayanan nyaman memiliki hubungan kuat dengan teknisi memiliki peralatan } \\
\text { kantor }\end{array}$ \\
\hline 4 & $\begin{array}{l}\text { Mudah mengakses website PT. X kapan saja memiliki hubungan kuat dengan Kualitas } \\
\text { SDM dan Ketersediaan SDM }\end{array}$ \\
\hline 5 & $\begin{array}{l}\text { Pelayanan pegawai cepat memiliki hubungan kuat dengan Prosedur sistem yang jelas dan } \\
\text { Pelatihan SDM }\end{array}$ \\
\hline 6 & $\begin{array}{l}\text { Ketepatan dalam menginput data oleh pegawai memiliki hubungan kuat dengan pelatihan } \\
\text { SDM }\end{array}$ \\
\hline 7 & $\begin{array}{l}\text { Kesesuaian dengan estimasi waktu yang dijanjikan memiliki hubungan kuat dengan } \\
\text { Peralatan kantor dan Pelatihan SDM }\end{array}$ \\
\hline 8 & $\begin{array}{l}\text { Besarnya tarif memiliki hubungan kuat dengan Ketersediaan modal tetap dan Peralatan } \\
\text { kantor }\end{array}$ \\
\hline 9 & $\begin{array}{l}\text { Pegawai tanggap terhadap kebutuhan pelanggan memiliki hubungan kuat dengan kualitas } \\
\text { SDM, ketersediaan SDM dan pelatihan SDM }\end{array}$ \\
\hline 10 & $\begin{array}{l}\text { Petunjuk yang diberikan oleh pegawai PT. X memiliki hubungan kuat dengan kualitas } \\
\text { SDM dan pelatihan SDM }\end{array}$ \\
\hline
\end{tabular}


Dina Paulina, Desain Kualitas Jasa Pengiriman...

Lanjutan Tabel 17.

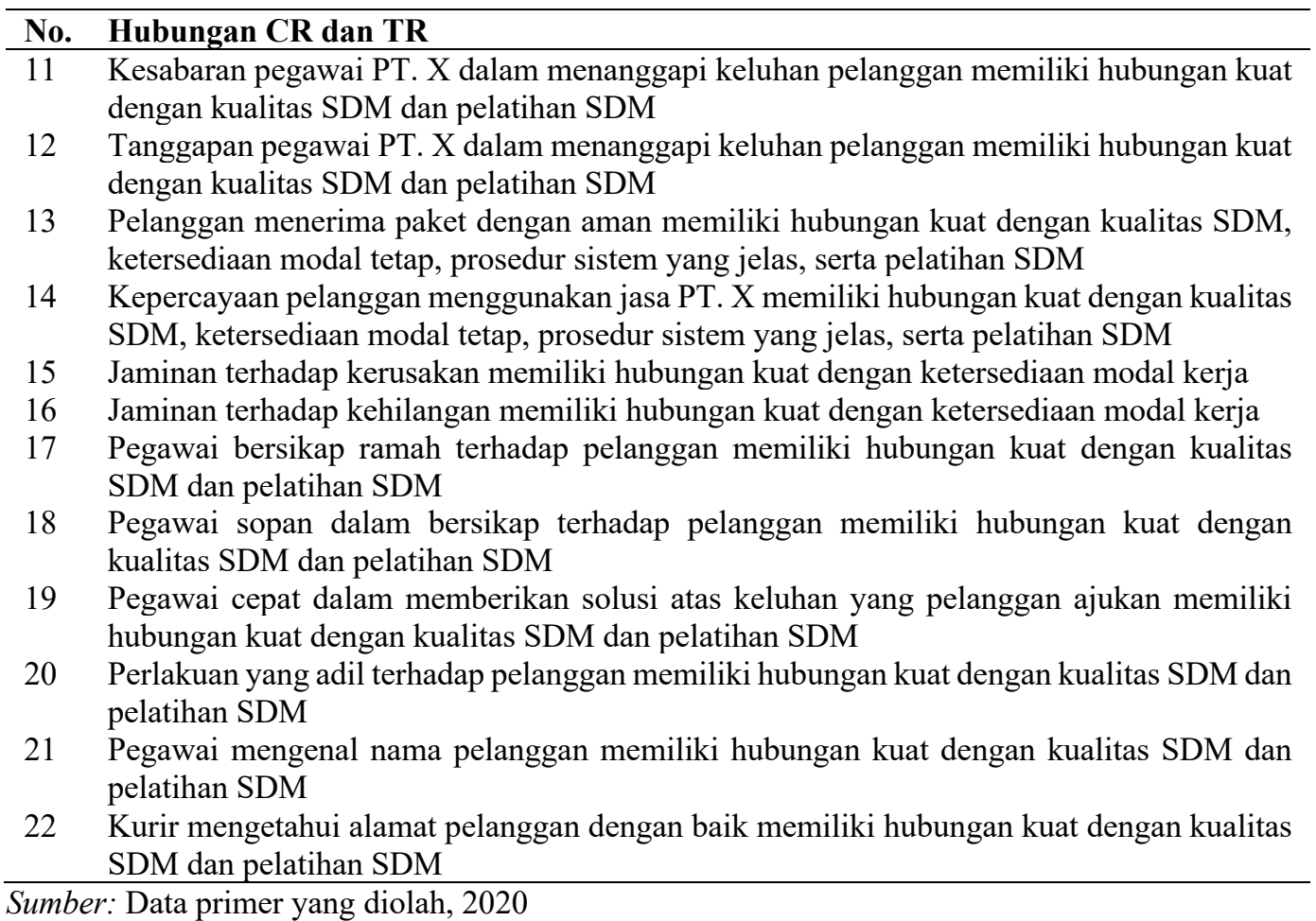

Hubungan sedang antara CR dan TR yang disimbolkan dengan "•" yang berarti CR cukup terpengaruhi oleh TR seperti yang dijabarkan pada Tabel 18.

Tabel 18.

Hubungan sedang antara CR dan TR

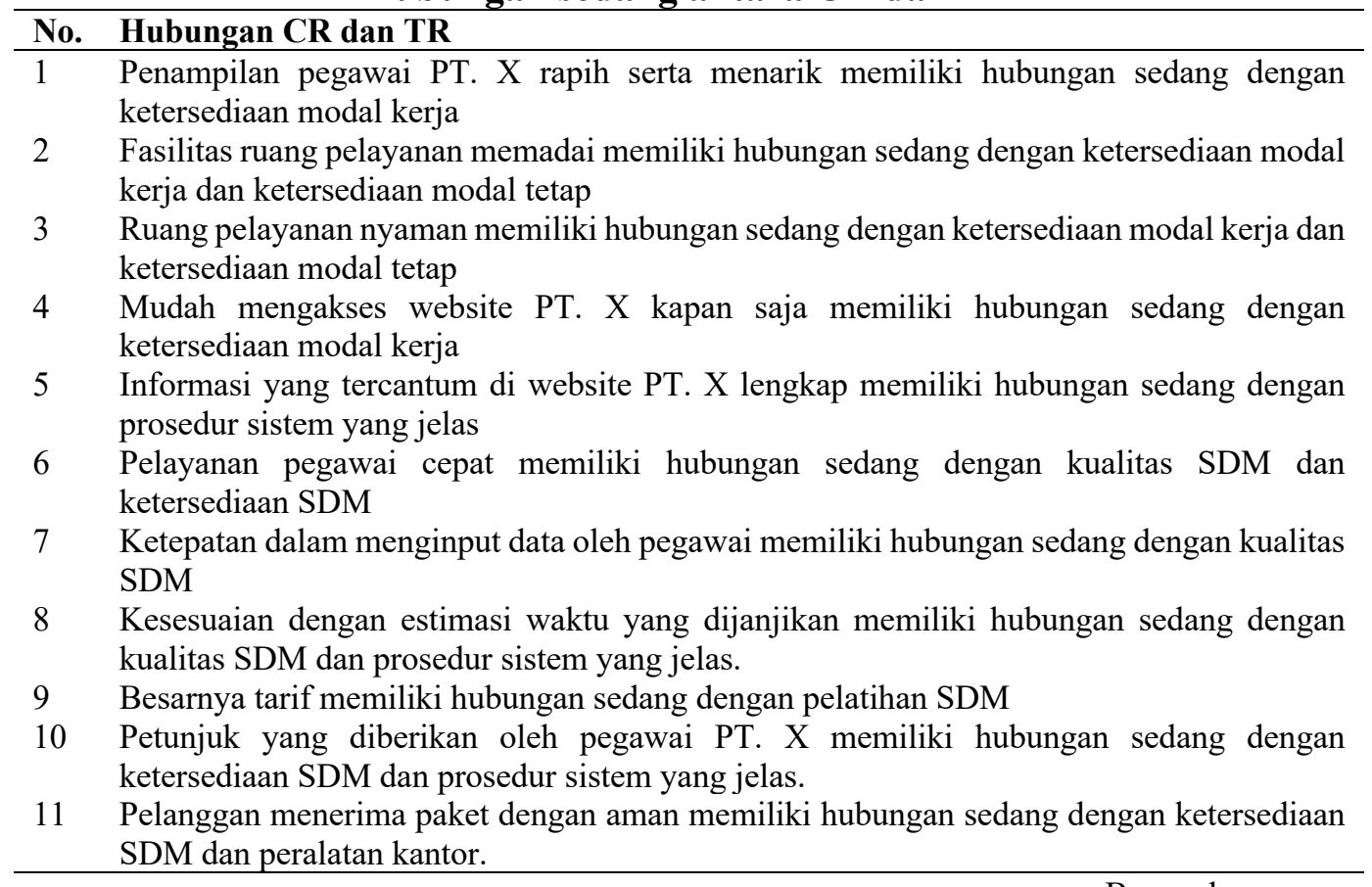

Bersambung...... 
Lanjutan Tabel 18.

No. Hubungan CR dan TR

12 Kepercayaan pelanggan menggunakan jasa PT. X memiliki hubungan sedang dengan ketersediaan SDM.

13 Jaminan terhadap kerusakan memiliki hubungan sedang prosedur sistem yang jelas

14 Jaminan terhadap kehilangan memiliki hubungan sedang dengan prosedur sistem yang jelas

Sumber: Data primer yang diolah, 2020

Hubungan rendah antara CR dan TR yang disimbolkan dengan " $\nabla$ " yang berarti TR sedikit terpengaruhi oleh TR, hubungan rendah ini ada sebanyak 5 hubungan, seperti yang dijabarkan pada Tabel 19.

Tabel 19.

Hubungan rendah antara CR dan TR

\begin{tabular}{ll}
\hline No. & Hubungan CR dan TR \\
1 & $\begin{array}{l}\text { Penampilan pegawai PT. X rapi serta menarik memiliki hubungan rendah dengan kualitas } \\
\text { SDM }\end{array}$ \\
2 & $\begin{array}{l}\text { Besarnya tarif memiliki hubungan sedang dengan prosedur sistem yang jelas } \\
\text { Kesabaran pegawai PT. X dalam menanggapi keluhan pelanggan memiliki hubungan } \\
\text { rendah dengan peralatan kantor }\end{array}$ \\
4 & $\begin{array}{l}\text { Tanggapan pegawai PT. X dalam menanggapi keluhan pelanggan memiliki hubungan } \\
\text { rendah dengan peralatan kantor } \\
\text { Pegawai bersikap ramah terhadap pelanggan memiliki hubungan rendah dengan } \\
\text { ketersediaan SDM }\end{array}$ \\
Sumber: Data primer yang diolah, 2020
\end{tabular}

Sementara sisanya tidak terdapat hubungan antara CR dan TR. Untuk dapat memenuhi keinginan konsumen atau CR maka diterjemahkan dengan TR, namun TR sendiri memerlukan standar sehingga dapat menunjang perusahaan dalam memenuhi keinginan konsumen. PT. X memiliki TR yang dibawah standar yang telah ditentukan jika dibandingkan dengan pesaingnya. Hal yang perlu ditingkatkan oleh PT. X adalah pada bagian pelatihan SDM, ketersediaan SDM, kualitas SDM, dan ketersediaan modal tetap dan kerjas.

Hubungan sangat tinggi antar TR ditunjukkan dengan simbol " $\bigcirc$ ” yang berarti sangat berpengaruh satu sama lain, seperti yang dijabarkan pada Tabel 20

Tabel 20.

\section{Hubungan sangat tinggi antara TR}

\section{No. Hubungan antar TR}

1 Kualitas SDM memiliki hubungan sangat tinggi dengan ketersediaan modal tetap, prosedur sistem yang jelas, serta pelatihan SDM

2 Ketersediaan SDM memiliki hubungan sangat tinggi dengan ketersediaan modal tetap

3 Ketersediaan modal kerja memiliki hubungan sangat tinggi dengan peralatan kantor dan prosedur sistem yang jelas

4 Ketersediaan modal tetap memiliki hubungan kuat dengan peralatan kantor, prosedur sistem yang jelas, dan pelatihan SDM

$5 \quad$ Peralatan kantor memiliki hubungan sangat tinggi dengan adanya prosedur sistem yang jelas

6 Prosedur sistem yang jelas memiliki hubungan sangat tinggi dengan pelatihan SDM

Sumber: Data primer yang diolah, 2020 
Dina Paulina, Desain Kualitas Jasa Pengiriman...

Hubungan sedang antar TR disimbolkan dengan “•” yang berarti cukup berpengaruh satu sama lain, seperti yang dijabarkan pada Tabel 21

Tabel 21.

Hubungan sedang antara TR

\begin{tabular}{ll}
\hline No. & Hubungan antar TR \\
1 & Kualitas SDM memiliki hubungan medium dengan ketersediaan SDM \\
2 & Ketersediaan SDM memiliki hubungan medium dengan prosedur sistem yang jelas \\
3 & Peralatan kantor memiliki hubungan medium dengan pelatihan SDM. Sisanya tidak \\
& terdapat hubungan korelasi antar TR \\
Sumber: Data primer yang diolah, 2020
\end{tabular}

Jika dibandingkan dengan kompetitornya PT. X mendapat 2 indikator yang dinilai dengan mendapat penilaian Sangat Baik (5), yaitu kesesuaian dengan estimasi waktu yang dijanjikan dan pelanggan menerima paket dengan aman, 20 indikator yang dinilai dengan mendapat penilaian Baik (4) dan 1 indikator sisanya mendapat nilai Kurang Baik (2).

Kompetitornya yaitu PT. Y mendapat Sangat Baik (5) sebanyak 12 indikator, yaitu fasilitas ruang pelayanan memadai, mudah mengakses website PT. X kapan saja, pelayanan pegawai cepat, ketepatan dalam menginput data oleh pegawai, kesesuaian dengan estimasi waktu yang dijanjikan, kesabaran pegawai PT. X dalam menanggapi keluhan pelanggan, tanggapan pegawai PT. X dalam menanggapi keluhan pelanggan, pelanggan menerima paket dengan aman, jaminan terhadap kerusakan, pegawai bersikap ramah terhadap pelanggan, pegawai cepat dalam memberikan solusi atas keluhan yang pelanggan ajukan, serta perlakuan yang adil terhadap pelanggan, dan 11 indikator sisanya dapat penilaian dengan mendapat penilaian Baik (4).

Kompetitor lainnya PT. Z mendapat Sangat Baik (5) sebanyak 7 indikator, yaitu penampilan pegawai PT. X rapih serta menarik, ruang pelayanan nyaman, pegawai tanggap terhadap kebutuhan pelanggan, petunjuk yang diberikan oleh pegawai PT. X, pelanggan menerima paket dengan aman, kepercayaan pelanggan menggunakan jasa PT. X, serta pegawai sopan dalam bersikap terhadap pelanggan, dan 16 indikator sisanya dapat penilaian dengan mendapat penilaian Baik (4).

PT. X menetapkan Target TR dengan skor 5, namun setelah TR dianalisis menunjukkan bahwa perusahaan belum mencapai target. TR yang sudah mencapai target hanya prosedur sistem yang jelas. TR yang mendapatkan skor 4 adalah kualitas SDM karena beberapa pegawai belum maksimal dalam bekerja keras dan berkarakter ramah, ketersediaan modal kerja karena kas saat ini hanya mencapai cukup namun lebih baik jika lebih dari cukup, ketersediaan modal tetap karena jumlah motor sebaiknya lebih dari jumlah kurir untuk berjaga-jaga, dan peralatan kantor karena kualitas gadget yang lebih baik dapat memperlancar kegiatan ekspedisi, sisanya TR yang mendapatkan skor 3 adalah ketersediaan SDM karena saat akhir tahun dan Hari Belanja Nasional kekurangan kurir karena jumlah permintaan yang tinggi dan pelatihan SDM karena PT. X belum menerapkan evaluasi secara berkala. 


\section{SIMPULAN}

Hubungan customer requirement yang kuat dengan technical requirement paling banyak jumlahnya terhubung dengan kualitas SDM dan pelatihan SDM, hal ini menunjukkan perbaikan pada kedua service elemen tersebut dapat memenuhi keinginan konsumen. Hubungan yang sedang dan lemah dapat memenuhi keinginan konsumen namun tidak sekuat kedua service elemen tersebut. Hubungan antar technical requirement sebagian besar terhubung kuat, hal ini menunjukkan bahwa sevice elemen sangat berpengaruh satu sama lain dan mendukung perbaikan service elemen yang terhubung. Dilihat dari penilaian konsumen rata-rata pelayanan PT. X masih dibawah pesaingnya, karena perusahaan relatif lebih mudah umurnya. Technical requirement yang sudah mencapai target hanya prosedur sistem yang jelas sisanya masih belum bisa mencapai target karena beberapa faktor berikut: pegawai belum maksimal dalam bekerja keras dan berkarakter ramah, kas pada modal kerja saat ini hanya mencapai cukup akan lebih baik jika lebih dari cukup, jumlah motor hanya sejumlah kurir akan lebih baik jika jumlahnya lebih untuk berjaga-jaga jika ada kendala, kualitas gadget yang kurang optimal, saat akhir tahun dan Hari Online Shop Nasional PT. X kekurangan kurir karena jumlah permintaan yang tinggi dan belum menerapkan evaluasi SDM secara berkala.

Berdasarkan hasil penelitian yang diperoleh PT. X diharapkan memperhatikan kualitas pegawai dan pelatihannya agar lebih mengenal nama pelanggan. Penelitian selanjutnya akan lebih baik jika menambahkan variabelvariabel lain selain dimensi kualitas jasa yang dapat mendukung perusahaan ekspedisi PT. X dalam meningkatkan kualitas pelayanannya. Dengan menggunakan variabel dan teknik analisis yang sama, peneliti menyarankan untuk memperluas cakupan penelitian, tidak hanya PT. X, namun terhadap perusahaan ekspedisi lainnya.

\section{REFERENSI}

Asmarawati, C. I., \& Purnomo, H. (2017). Desain Kipas Angin Neodymium Menggunakan Metode Quality Function Deployment (QFD). IENACO, 53(9), 1689-1699.

Bajčetić, S., Tica, S., Živanović, P., Milovanović, B., \& Đorojević, A. (2018). Analysis of public transport users' satisfaction using quality function deployment: Belgrade case study. Transport, 33(3), 609-618. https://doi.org/10.3846/transport.2018.1570

Chen, S. H. (2016). Determining the service demands of an aging population by integrating QFD and FMEA method. Quality and Quantity, 50(1), 283-298. https://doi.org/10.1007/s11135-014-0148-y

Cheng, C.-C., Tsai, M.-C., \& Lin, S.-P. (2015). Developing Strategies for Improving the Service Quality of Casual-Dining Restaurants: New Insights 
from Integrating IPGA and QFD Analysis. Total Quality Management \& Business Excellence, 26(3), 415-429. https://doi.org/https://doi.org/10.1080/14783363.2013.839166

Chowdhury, M. M., \& Quaddus, M. A. (2016). A Multi-Phased QFD Based Optimization Approach To Sustainable Service Design. Int. J. Production Economics, 171(1), 165-178. https://doi.org/10.1016/j.ijpe.2015.09.023

Dewi, S. K. (2017). Analisis Kualitas Pelayanan Dengan Metode SERVQUAL. Seminar Nasional Teknologi Dan Rekayasa (SENTRA), III, 1-9.

Dhika, A., Lukman, \& Fitriansyah, A. (2016). Perancangan Sistem Informasi Jasa Pengiriman Barang Berbasis Web. Jurnal SIMETRIS, 7(1), 1-20. https://doi.org/https://doi.org/10.24176/simet.v7i1.487

Escola, M. (2018). Integrated triz with qfd applied to automotive valve industry. HOLOS, 01(34), 50-60. https://doi.org/10.15628/holos.2018.6669

Hartanti, F. T., Luh, N., \& Hariastuti, P. (2015). Integrasi Servqual Dan QFD Untuk Meningkatkan Kualitas Pelayanan Di Tempat Rekreasi Kenjeran. Seminar Nasional Sains Dan Teknologi Terapan, III, 97-106.

Hussain, R., Nasser, A. A., \& Hussain, Y. K. (2015). Service Quality and Customer Satisfaction of a UAE-based Airline: An Empirical Investigation. Journal of Air Transport Management, 42(1), 167-175.

Kasan, A., \& Yohanes, A. (2017). Improvement produk hammock sleeping bag dengan metode qfd ( quality function deployment). Dinakmika Teknik, 10(1), $40-49$.

Kelesbayev, D., Kalykulov, K., Yertayev, Y., Turlybekova, A., \& Kamalov, A. (2016). A case study for using the quality function deployment method as a quality improvement tool in the universities. International Review of Management and Marketing, 6(3), 569-576.

Lam, J. S. L., \& Dai, J. (2015). Developing Supply Chainnsecurity Design of Logistics Service Providers: An Analytical Network Process-Quality Function Deployment Approach. International Journal of Physical Distribution \& Logistics Management, 45(7), 674-690.

Lin, C., Choy, K. L., \& Ho, G. T. S. (2015). A Decision Support System for Optimizing Dynamic Courier Routing 4 Operations. Expert Systems with Applications, 17(1), 1-20.

Noer, L. R., Ciptomulyono, U., \& Sudarso, I. (2015). Analisis Peningkatan Kualitas Pelayanan Pelanggan PT. Pos Indonesia Persero Kantor Wilayah Surabaya 
Selatan Dengan Metode SERVQUAL, Metode Model Kano, Dan Quality Function Deployment (QFD). Jurnal Nasional Manajemen Teknologi, 5(1), 120.

Pakdil, F., \& Kurtulmuşoğlu, F. B. (2015). Improving Service Quality in Highway Passenger Transportation: A Case Study Using Quality Function Deployment. EJTIR, 1(11), 375-393.

Pranata, I. M. A., \& Darma, G. S. (2014). Strategi Penerapan E-Commerce Dalam Meningkatkan Keunggulan Bersaing. Jurnal Manajemen Dan Bisnis, 11(1), $1-20$.

Shrivastava, P., \& Verma, D. S. (2016). Application of Quality Function Deployment To Improve Customer Satisfaction In Hotel Industry. International Journal of Scientific \& Engineering Research, 6(5), 1-20.

Siregar, K., Ginting, R., Siregar, I., Industri, D. T., Teknik, F., \& Utara, U. S. (2017). Penyusunan Kebutuhan Perancangan Mesin Hemodialisis Menggunakan Kansei Engineering Serta Aplikasi QFD dan TRIZ. Media Teknika Jurnal Teknologi, 12(1), 1-9.

Sun, R., Gregor, S., \& Keating, B. (2015). Information Technology Platforms: Conceptualisation and a Review of Emerging Research in IS Research. Australasian Conference on Information Systems, 21(1), 1-10.

Suryopratomo, A. (2019). Strategi Pengembangan Kualitas Pelayanan untuk Memenuhi Keinginan Konsumen Pada Bengkel Wijaya Toyota. Ekonam, 1(1), $39-54$.

Sutawidjaya, Ahmad \& Asmarani, P. (2018). Evaluasi Pelayanan Publik Produk hukumonline.com Untuk Mengetahui Kebutuhan Pelanggan Kasus Pt Justika Siar Publika. Jurnal JDM, I(02), 32-45.

Tejedor, A. C. P., Tejedor, J. P., \& Elola, L. N. (2016). A Guide To Business Management Diagnosis Applied To A Logistic Warehouse. The Business and Management Review, 7(5), 1-20.

Tyasdela, A. A. P. C., Satriawan, I. K., \& Wiranatha, A. A. P. A. S. (2015). Penerapan Metode Quality Function Deployment Dalam Upaya Memenuhi Kepuasan Pelanggan Terhadap Layanan Pesan Antar Pizza (Studi Kasus pada S2 Pizza, Bali). Jurnal Rekayasa Dan Manajemen Agroindustri, 3(3), 1-20.

Valaei, N., Shahijan, M. K., \& Rezaei, S. (2016). CouQual: Assessing Overall Service Quality in Courier Service Industry and the Moderating Impact of Age, Gender and Ethnicity. International Journal of Management Concepts and Philosophy, 1(1), 1-20. https://doi.org/10.1504/IJMCP.2016.077770 
Dina Paulina, Desain Kualitas Jasa Pengiriman...

Yuen, K. F., \& Thai, V. V. (2015). Service Quality and Customer Satisfaction in Liner Shipping. International Journal of Quality and Service Sciences, 1(1), 170-183. 